\title{
PENGARUH ALOKASI DANA DESA DAN BADAN USAHA MILIK DESA TERHADAP PENDAPATAN ASLI DESA
}

\section{Anggi Anggara}

Universitas Muhammadiyah Sukabumi Jawa Barat, Indonesia

Email: anggianggara1998@ummi.ac.id

\begin{tabular}{l}
\hline INFO ARTIKEL \\
\hline Diterima \\
12 Februari 2021 \\
Direvisi \\
22 Februari 2021 \\
Disetujui \\
15 Maret 2021
\end{tabular}

\section{Keywords:}

allocation of village funds; village owned enterprises; village native income

\begin{abstract}
ABSTRACK
In this study, the village was motivated by Cilograng Village, Allocation of Village Funds and Village Owned Enterprises as a source of village finance that can be used as Village Native Income. This could cause the village government to depend on transfer funds from the central government which causes the village government
\end{abstract} to not be independent in the management of the village. The population in this study is the financial report of Cilograng Village Government for Fiscal Year 20182020. In the study using quantitative approach with sempel retrieval with purposive sampling technique. Data collection techniques using secondary data. The data analysis techniques used are classic assumption test, multiple linear analysis, hypothesis test and determination coefficient test. The results of this study showed: free variables are allocation of village funds and village owned enterprises while the variable is tied to the Village's Original Income. The results of this study showed that partial allocation of village funds had an effect on the t test result of 2,260 with a significance level of 0.031. Then it can be concluded that the Allocation of Village Funds and Village Owned Enterprises affects the Village's Original Income. The objectives to be achieved from this research are to know the influence of village fund allocation on village native income, to know the influence of BUMDes on village native income, and to know the influence of village fund allocation and BUMDes on village native income.

\footnotetext{
ABSTRAK

Penelitian ini dilatar belakangi di Desa Cilograng, Alokasi Dana Desa dan Badan Usaha Milik Desa sebagai sumber keuangan desa yang bisa dijadikan Pendapatan Asli Desa. Hal ini bisa menyebabkan pemerintah desa tergantung dengan dana transfer dari pemerintah pusat yang menyebabkan pemerintahan desa tidak bisa mandiri
} 


\section{Kata Kunci :}

alokasi dana desa; badan usaha milik desa; pendapatan asli desa dalam pengelolaan desanya. Populasi dalam penelitian ini adalah laporan keuangan Pemerintahan Desa Cilograng Tahun Anggaran 2018-2020. Dalam penelitian menggunakan pendekatan kuantitatif dengan pengambilan sempel dengan teknik purposive sampling. Teknik pengumpulan datanya dengan menggunakan data sekunder. Teknik analisis data yang digunakan adalah uji asumsi klasik, analisis linear berganda, uji hipotesis dan uji koefisien determinasi. Hasil penelitian ini menunjukan: variabel bebas yaitu Alokasi Dana Desa dan Badan Usaha Milik Desa sedangkan variabel terikat yaitu Pendapatan Asli Desa. Hasil penelitian ini menunjukan bahwa secara parsial Alokasi Dana Desa berpengaruh terhadap dengan hasil uji t sebesar 2,260 dengan tingkat signifikansi 0,031. Maka dapat diambil kesimpulan bahwa Alokasi Dana Desa dan Badan Usaha Milik Desa berpengaruh terhadap Pendapatan Asli Desa. Tujuan yang ingin dicapai dari penelitian ini adalah untuk mengetahui pengaruh alokasi dana desa terhadap pendapatan asli desa, untuk mengetahui pengaruh BUMDes terhadap pendapatan asli desa, dan untuk mengetahui pengaruh alokasi dana desa dan BUMDes terhadap pendapatan asli desa.

Coresponden Author

Email: anggianggara1998@ummi.ac.id Artikel dengan akses terbuka dibawah lisensi

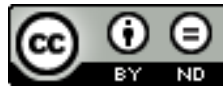

\section{Pendahuluan}

Berdasarkan Undang-Undang No. 6 Tahun 2014 tentang desa pada pasal 72 ayat (4), bahwa dana desa yang diberikan ke desa-desa di seluruh Indonesia yang berasal dari Anggaran Pendapatan dan Belanja Negara (APBN) sebesar 10\% yang langsung diturunkan melalui rekening pemerintah daerah kota/kabupaten, dimana jumlah dana desa yang diberikan ke desa berbeda-beda tergantung dari tingkat kebutuhan desa (Jeniary, 2018).

Pemerintah desa memiliki pendapatan desa yang terdiri dari pendapatan asli desa, dana desa, alokasi dana desa, dan pendapatan transfer bagi hasil pajak dan retribusi daerah (Purbasari et al., 2018). Pendapatan Asli Desa (PADes) adalah pendapatan yang diterima secara mandiri dari desa tersebut misalnya seperti hasil usaha desa, hasil kekayaan desa, dan lain sebagainya (Astuti, 2013). Dalam pelaksanaanya, pemerintah desa dapat memprioritaskan dalam pembangunan dibidang pekerjaan umum yang terkait dengan sarana dan prasarana desa selain itu PADes juga digunakan untuk pengembangan potensi desa lainnya misalnya perekonomian, pertanian, perkebunan, perikanan dan lain sebagainya (Susanto \& Iqbal, 2019). 
Alokasi dana desa yaitu dana yang di alokasikan oleh pemerintah kabupaten/kota untuk desa yang bersumber dari dana perimbangan keuangan pusat dan daerah yang diterima oleh kabupaten/kota yang paling sedikit 10\% yang telah dikurangi dana alokasi khusus yang bersumber langsung daerah APBD (Arifin, 2018). Alokasi dana desa merupakan dana yang cukup signifikan bagi desa untuk menunjang program-program jangka pendek dan jangka panjang desa, seperti pembangunan jalan ke perkampungan untuk jangka pendek dan seperti pemberdayaan ekonomi masyarakat untuk jangka Panjang (Hariyanto \& Mutiarin, 2016).

Badan Usaha Milik Desa (BUMDes) telah diamanatkan di dalam Permendesa PDTT Nomor 4 Tahun 2015 tentang Pendirian, Pengurusan, dan Pengelolaan, dan Pembubaran Badan Usaha Milik Desa dimaksudkan untuk melaksanakan ketentuan Pasal 142 Peraturan Pemerintah Nomor 43 Tahun 2014 tentang Peraturan Pelaksanaan Undang-Undang Nomor 6 Tahun 2014 tentang Desa (Darmandika, 2020). BUMDes harus disertai dengan penguatan kapasitas dan dukungan dari pemerintah (kebijakan) yang memfasilitasi dan melingdungi usaha ini dari ancaman persaingan para pemodal besar, karena BUMDes ini dibentuk untuk membantu pemerintah desa untuk mengelola desanya agar lebih sejahtera dan mandiri, khususnya dalam bidang perekonomian desa (Kadir \& Lubis, 2019).

Dilansir www.beritasatu.com dari Alokasi dana desa untuk Kabupaten Lebak yaitu sebesar Rp. 432.9 Miliar pada tahun 2019, dana sebesar itu bersumber dari APBN sebesar Rp. 286.7 Miliar, alokasi dana desa APBD Kabupaten sebesar Rp. 119.4 Miliar dana bagi hasil pajak dan retribusi daerah Kabupaten Rp. 9.6 Miliar dan bantuan keuangan dari APBD Provinsi Banten sebesar Rp. 17 Miliar, dikutip dari berita satu tentang dana desa tahun 2019.

Dari Peraturan Bupati Lebak Nomor 66 Tahun 2018 bahwa Alokasi dana desa untuk tahun anggaran 2019 sebesar Rp. 316.120.000 perdesa dengan dibagi 10 Desa dengan alokasi formula yang tiap Desa berbeda termasuk Desa Cilograng yang mendapatkan alokasi formula sebesar Rp. 23,428,000 dan pagu alokasi dana desa sebesar Rp. 339,558,000. Dengan perhitungan rumus dana desa = Alokasi Dasar + Alokasi Formula. Alokasi dasar yaitu alokasi minimal dana desa yang akan diterima oleh setiap desa, yang besaran jumlahnya dihitung dengan menggunakan mencari $90 \%$ dari anggaran dana desa dengan dibagi jumlah desa secara nasional dan sebesar $10 \%$ berdasarkan jumlah penduduk desa, angka kemiskinan yang ada di desa, dan luas wilayah desa, dengan bobot variabel maksimal 30\% (Azwardi \& Sukanto, 2014).

Menurut laporan keuangan Desa Cilograng pendapatan asli Desa Cilograng pada tahun 2016-2020 mengalami ketidakstabilan dengan kenaikan paling tinggi terjadi pada tahun 2017 mencapai Rp. 6.027.000 dan penurunan yang paling terendah terjadi pada tahun 2016 mencapai Rp. 520.000 sedangkan pada tahun 2018 pendapatan asli Desa Cilograng mencapai Rp. 837.721 dan mengalami kenaikan lagi pada tahun 2019-2020 dengan kenaikan yang sama yaitu Rp. 2.000.000. Melihat dari fenomena yang ada bahwa pendapatan asli Desa Cilograng masih belum stabil dari tahun ke tahun masih bisa dikatakan bahwa pemerintahan Desa Cilograng harus lebih baik lagi dalam 
pengelolaan pendapatan asli desa yang akan berdampak positif bagi kemajuan Desa Cilograng itu sendiri.

Permasalahan yang ada dimasyarakat terjadi ketika pemerintah desa berani menyelewengkan anggaran yang ada, seperti yang terjadi pada tahun 2017 di Kabupaten Sukabumi yang dilansir berita online www.news.detik.com mantan Kepala Desa Bantargebang Kecamatan Bantar Gadung pada tahun 2017 menyelewengkan dana desa sebesar Rp. 781.996 .376 dan pada tahun 2018 negara menanggung kerugian sebesar Rp. 557.874.931 berdasarkan hasil pemeriksaan dari inspektorat Kabupaten Sukabumi.

Menurut takanews.com fenomena yang terjadi dimasyarakat yaitu BUMDes sangat berguna bagi kemajuan dan kemandirian desa tersebut, seperti yang terjadi di Desa Wakalambe Kecamatan Kapontori Kabupaten Buton, Sulawesi Tenggara pada tahun 2019 bisa mendapatkan keuntungan sebesar Rp. 58 juta dari hasil pembuatan bata merah dan simpan pinjam dari kegiatan BUMDes tersebut dan membuat desa tersebut bisa dikatakan sudah mandiri dari pengelolaan BUMDes.

Melihat dari jumlah yang sangat begitu besar untuk pengelolaan desa dan fenomena yang bisa diambil untuk dijadikan pandangan bahwa keberadaan BUMDes bisa sangat berguna untuk menyejahterakan masyarakat desa tersebut melalui PADes. Pendapatan asli desa di Desa Cilograng terdapat beberapa potensi yang belum dioptimalkan oleh pemerintah desa, berpotensi sebagai pendapatan asli desa, diantaranya: optimalisasi pengembangan BUMDes, mendirikan pasar desa, serta potensi dalam BUMDes yaitu desa wisata dan mengoptimalkan potensi objek wisata pantai. Pembentukan BUMDes seharusnya dapat memberikan keuntungan bagi desa khususnya dari segi pendapatan asli desa, yang akan sangat berguna untuk bisa memajukan dan mesejahterakan masyarakat desa, akan tetapi situasi dilapangan tidak sesuai dengan apa yang masyarakat bayangkan, masih banyak masyarakat yang kurang paham dengan kegunaan dan tujuan adanya BUMDes itu sendiri (Atmojo, 2015). Dengan melihat situasi yang seperti itu seharusnya pemerintah desa harus mensosialisasikan agar masyarakat lebih bisa untuk mendukung dan berpartisifasi dalam setiap pembangunan yang dilakukan oleh pemerintah yang yang bertujuan untuk mengembangkan segala potensi yang ada di Desa Cilograng.

Berdasarkan latar belakang, penulis mengambil beberapa poin yang akan dijadikan sebagai identifikasi masalah adalah pengelolaan anggaran alokasi dana desa masih kurang optimal, keterbukaan dalam pengalokasian dana desa tidak transparan, pengalokasian dana desa untuk kegiatan BUMDes masih minim (Kholmi, 2017), kegiatan BUMDes di Desa Cilograng masih belum berjalan, pendapatan asli Desa Cilograng masih kurang, dan kegiatan BUMDes untuk pendapatan asli desa belum berdampak positif.

Berdasarkan latar belakang masalah diatas maka permasalahan yang dihadapi adanya persamaan antara penelitian-penelitian terdahulu yaitu: alokasi dana desa berkontribusi dalam kenaikan pendapatan asli desa dengan alokasi dana desa sebagai salah satu sumber keuangan desa, badan Usaha Milik Desa sebagai program dari usaha yang pemerintah desa buat berkontribusi untuk dijadikan sumber pendapatan asli desa. 
Tujuan yang ingin dicapai dari penelitian ini adalah untuk mengetahui pengaruh alokasi dana desa terhadap pendapatan asli desa, untuk mengetahui pengaruh BUMDes terhadap pendapatan asli desa, dan untuk mengetahui pengaruh alokasi dana desa dan BUMDes terhadap pendapatan asli desa.

\section{Metode Penelitian}

Menurut (Kurniawan, 2020) metode penelitian kuantitatif yaiitu metode penelitian yang berlandaskan pada filsafat positivisme, digunakan untuk meneliti pada populasi atau sampel tertentu, teknik pengambilan sampel pada umumya dilakukan secara random atau acak dan menggunakan instrument penelitian. Menurut (Kurniawan, 2020) penelitian asosiatif yaitu penelitian yang bertujuan untuk mengetahui pengaruh atapun juga hubungan antara dua variable atau lebih. Metedologi penelitian ini menggunakan metedologi penelitian kuantitatif dengan menggunakan pendekatan asosiatif. Objek dalam penelitian ini adalah menerapkan pendekatan pada akuntansi sector publik atau akuntansi pemerintahan yang lebih khusus dalam pengelolaan Alokasi Dana Desa (ADD) dan Badan Usaha Milik Desa (BUMDes) dan Pendapatan Asli Desa.

\section{Hasil dan Pembahasan}

\section{Deskriptif statistik}

Dari hasil uji deskriptif statistik menunjukan bahwa sampel $(\mathrm{N})$ yaitu sebanyak 36 data yang diambil dari laporan realisasi alokasi dana desa, laporan pendapatan BUMDes, dan laporan pendapatan asli desa per-tahun anggaran 2018-2020 selama 36 bulan. Alokasi dana desa nilai maksimalnya atau nilai paling tinggi sebesar 346.120.000, nilai minimalnya 0 , nilai mean $157.105 .773,61$, dan nilai standart deviation yaitu 105.934.311,13.

Badan Usaha Milik Desa nilai tertingginya yaitu 6.500.000, nilai mean yaitu 1.233.333.33 dan nilai standart deviation yaitu 1.680.986,10. Pendapatan asli desa nilai tertingginya sebesar 3.150 .032 , nilai minimumnya 0 , dan nilai standart deviation pendapatan asli desa sebesar 685.890,04.

\section{Uji Asumsi Klasik}

\section{a. Uji Normalitas}

Uji one-sample komolgorov-smirnov test menunjukan bahwa nilai Asymp, sig (2-tailed) pada tabel diatas menunjukan angka 0,001. Karena signifikannya kecil dari dari $0,05(0,05>0,001)$ maka nilai residual dapat dikatakan berdistribusi tidak normal. 


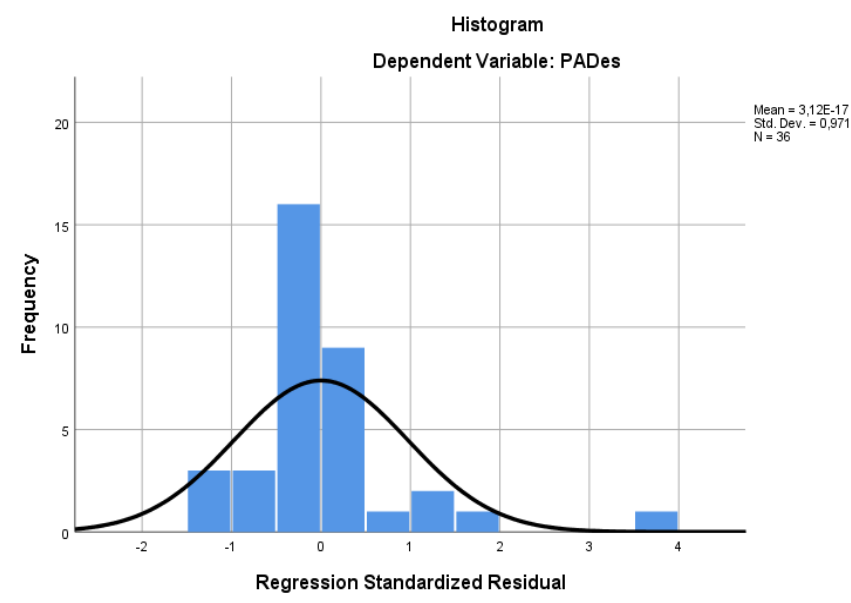

Grafik 1 Histogram

Dari grafik histogram diatas dapat diambil kesimpulan bahwa kurva tidak berbentuk lonceng dan lebih condong ke kiri dan kanan sehingga dapat diambil kesimpulan bahwa data tersebut tidak berdistribusi normal.

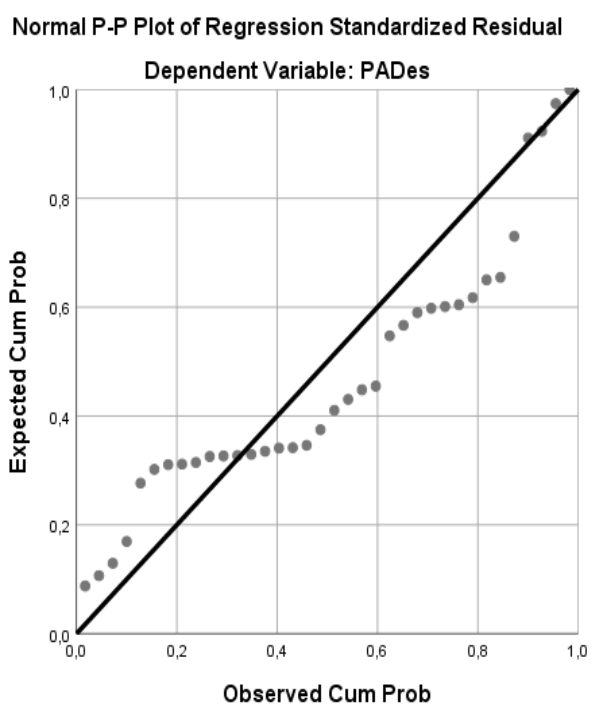

Grafik 2 Normal P-Plot

Gambar ditas menunjukan titik menyebar dari bagian atas dan bawah garis dan mengikuti arah garis diagonal tersebut. Sehingga model regresi diatas sudah dapat memenuhi asumsi uji normalitas.

b. Uji Multikoliearitas

Uji multikolinearitas menunjukkan bahwa perhitungan nilai tolerance sebesar 0,799 > 0,10 yang artinya tidak terjadi kolerasi antar variabel independen. Sedangkan untuk hasil pengujian VIF menunjukkan bahwa 1,251 < 10, sehingga dapat disimpulkan bahwa tidak terdapat gejala multikolinearitas antar variabel independen pada model regresi penelitian ini. 


\section{c. Uji Heteroskedatisitas}

Untuk menguji adanya heteroskedatisitas pada penelitian ini dengan menggunakan Glejser Test. Pengujian ini membandingkan signifikan dari hasil uji dengan sig >0,05 atau 5\%. Jika signifikan diatas 5\% maka disimpulkan model regresi tidak mengandung adanya heteroskedastisitas. Jika varians residual suatu pengamatan ke pengamatan lainnya tetap, maka disebut homoskedatisitas dan jika berbeda disebut heteroskedasitas. Model yang baik yaitu homoskedastisitas atau tidak terjadi heteroskedatisitas.

\section{Analisis Regresi Linier Berganda}

$$
\mathrm{Y}=321867,567+0,001+0,379
$$

Persamaan regresi tersebut dapat diartikan sebagai berikut :

$$
\text { Nilai a (konstanta) }=321867,567
$$

Merupakan konstantan atau keadaan variabel Y (pendapatan asli desa) belum dipengaruhi oleh variabel X1 dan X2. Nilai variabel X1 (alokasi dana desa) dan X2 (Badan Usaha Milik Desa) bernilai O (nol) maka variabel Y (pendapatan asli desa) sebesar 321867,567.

$$
\text { Koefisien X1 = 0,001 }
$$

Merupakan Konstanta atau keadaan variabel X1 (alokasi dana desa) mempunyai pengaruh positif terhadap Pendapatan Asli Desa dengan asumsi variabel Alokasi Dana Desa (X1) sebesar 0,001.

\section{Koefisien X2 $=0,379$}

Merupakan Konstanta atau keadaan variable X2 (Badan Usaha Milik Desa) mempunyai pengaruh positif terhadap kenaikan satuan variabel Pendapatan Asli Desa (Y) dengan asumsi kenaikan sebesar 0,379.

\section{Uji Hipotesis}

a. Uji t

$$
\begin{aligned}
& \text { Rumus } \mathrm{t} \text { tabel }(\mathrm{a} / 2: \mathrm{n}-\mathrm{k}-1) \\
& \text { Ket a }=0,05(\text { tingkat kepercayaan } 95 \%) \\
& \mathrm{n}=\text { jumlah sampel } \\
& \mathrm{k}=\text { jumlah variabel independen }(\mathrm{X}) \\
& \text { Perhitungannya }:(0,005 / 2: 36-2-1) \mathrm{t}(0,025: 33)=2.032(\mathrm{t} \\
& \text { tabel })
\end{aligned}
$$

Berdasarkan perhitungan diatas diketahui nilai Sig untuk pengaruh X1 terhadap Y adalah sebesar 0,031>0,05 dan nilai t hitung 2,260>2,031, sehingga dapat diambil kesimpulan bahwa $\mathrm{H} 1$ diterima yang berarti terdapat pengaruh antara variabel X1 (Alokasi Dana Desa) terhadap variabel Y (Pendapatan Asli Desa). Berdasarkan Sig untuk pengaruh X2 terhadap Y adalah sebesar $0,000<$ 0,05 dan nilai t hitung 7,663 > 2,031 sehingga dapat diambil kesimpulan bahwa $\mathrm{H} 2$ diterima yang berarti terdapat pengaruh antara variabel $\mathrm{X} 2$ terhadap variabel Y. 
b. Uji f

$$
\begin{aligned}
& \text { Rumus } \mathrm{f}_{\text {tabel }}=\mathrm{f}(\mathrm{k}: \mathrm{n}-\mathrm{k}) \\
& \text { Ket }: \mathrm{k}=\text { jumlah variable bebas } \\
& \mathrm{n}=\text { jumlah sampel } \\
& \text { dijawab }: \mathrm{f}(2: 34)=3,32\left(\mathrm{f}_{\text {tabel }}\right)
\end{aligned}
$$

Berdasarkan perhitungan $\mathrm{f}$ tabel diatas diketahui nilai Sig untuk pengaruh antara variabel X1 dan X2 secara simultan terhadap Y adalah $0,000<0,05$ dan nilai $\mathrm{f}_{\text {hitung }}$ 29,383 > 3,32 sehingga dapat diambil kesimpulan bahwa H3 diterima yang berarti terdapat pengaruh antara X1 dan X2 secara simultan terhadap Y.

Uji Koefisien Determinasi $\left(\mathrm{R}^{2}\right)$

Nilai R Square sebesar 0,640 hal ini mempunyai arti bahwa pengaruh variabel $\mathrm{X} 1$ dan $\mathrm{X} 2$ secara simultan terhadap variabel $\mathrm{Y}$ sebesar 64,0\%. Hal ini bisa diambil kesimpulan bahwa $36,0 \%$ pengaruh terhadap variabel Y bisa terjadi karena adanya faktor-faktor lain yang tidak diteliti dalam penelitian ini, akan tetapi angka 64,0\% sudah bisa membuktikan bahwa alokasi dana desa dan Badan Usaha Milik Desa bisa sangat berpengaruh sedemikian signifikannya terhadap pendapatan asli desa.

1) Pengaruh alokasi dana desa terhadap pendapatan asli desa pada pemerintahan Desa Cilograng.

Berdasarkan uji t pada variabel X1 memiliki $t$ tabel yaitu 2,260 lebih besar daripada thitung 2,031 dengan nilai signifikansi 0,031 lebih besar daripada 0,05 maka dapat diartikan bahwa alokasi dana desa berpengaruh terhadap pendapatan asli desa. Maka dapat diambil kesimpulan bahwa $\mathrm{H}_{\mathrm{O} 1}$ dan $\mathrm{H}_{\mathrm{a} 1}$ diterima, yang berarti bahwa alokasi dana desa berpengaruh terhadap pendapatan asli desa pada pemerintahan Desa Cilograng tahun anggaran 2018-2020 dikarenakan jumlah alokasi dana desa sebagai salah satu sumber keuangan desa bisa menutupi kekurangan anggaran yang minim ketika pendapatan asli desa mengalami kekurang, terlebih lagi pada tahun 2020 pendapatan asli desa menurun drastis karena adanya pandemi Covid-19 yang membuat perekonomian mengalami penurunan.

Hasil penelitian ini sesuai dengan penelitian terdahulu yang dibuat oleh (Sulistiyoningtyas et al., 2017) yang berjudul pengaruh alokasi dana desa dan pendapatan asli desa terhadap belanja desa, meskipun berbeda variabel pendapatan asli desa akan tetapi bisa diambil kesimpulan bahwa pendapatan asli desa bisa mempengaruhi tingkat pertumbuhan ekonomi yang ada di desa tersebut dengan alokasi dana desa sebagai salah satu sumber keuangan yang desa.

2) Pengaruh Badan Usaha Milik Desa terhadap pendapatan asli desa pada pemerintahan Desa Cilograng

Berdasarkan uji t dapat diambil kesimpulan bahwa nilai t hitung 7,663 lebih besar dari pada 2,031 dan nilai Signifikansi 0,000 lebih kecil dari pada 0,05 maka 
dapat diartikan bahwa Badan Usaha Milik Desa berpengaruh terhadap pendapatan asli desa. Maka dapat diambil kesimpulan bahwa $\mathrm{H}_{\mathrm{O} 1}$ ditolak dan $\mathrm{H}_{\mathrm{a} 1}$ diterima yang berarti bahwa Badan Usaha Milik Desa berpengaruh terhadap pendapatan asli desa pada pemerintahan Desa Cilorang tahun anggaran 2018-2020.

Hal ini sesuai dengan jurnal penelitian terdahulu yang dibuat oleh (Tomisa \& Syafitri, 2020) dengan judul pengaruh Badan Usaha Milik Desa terhadap Pendapatan Asli Desa di Desa Sukajadi Kec. Bukit Batu Kab. Bengkalis dengan hasil penelitian Badan Usaha Milik Desa berpengaruh terhadap pendapatan asli desa.

3) Pengaruh alokasi dana desa dan Badan Usaha Milik Desa terhadap pendapatan asli desa pada pemerintahan Desa Cilograng TA 2018-2010

Dari hasil uji $\mathrm{f}$ bisa disimpulkan bahwa nilai signifikansi yaitu 0,000 lebih kecil daripada 0,05 dan nilai f hitung 29,383 lebih besar daripada $\mathrm{f}$ tabel 3,32 dengan asumsi $\mathrm{Ho}_{1}$ ditolak dan $\mathrm{H}_{\mathrm{a} 1}$ diterima maka dapat diambil kesimpulan bahwa alokasi dana desa dan Badan Usaha Milik Desa berpengaruh terhadap pendapatan asli desa pada pemerintahan Desa Cilograng pada tahun anggaran 2018-2020.

Hal tersebut sesuai dengan penelitian terdahulu yang dibuat oleh (Riza, 2019) dengan judul Pengaruh alokasi dana desa dan pendapatan asli desa terhadap kesejahteraan masyarakat, dengan kesimpulan bahwa alokasi dana desa sangat berpengaruh untuk mengembangkan perekonomian dan kesejahteraan masyarakat desa dan pendapatan asli desa berperan penting untuk menjadi salah satu sumber keuangan desa yang berasal dari hasil usaha, retribusi desa aset dan lain-lain yang dikelola dengan baik oleh pemerintah desa.

\section{Kesimpulan}

Penelitian ini dilakukan untuk mengetahui seberapa besar pengaruh alokasi dana desa, Badan Usaha Milik Desa terhadap pendapatan asli desa pada pemerintahan Desa Cilograng Tahun Anggaran 2018-2020 dengan melihat laporan keuangan. Berdasarkan pembahasan dan analisis penelitian ini, bisa diambil kesimpulan, yaitu: alokasi dana desa berpengaruh secara parsial terhadap pendapatan asli desa pada pemerintahan Desa Cilograng tahun anggaran 2018-2020 dengan hasil uji t sebesar 2,260 dengan tingkat signifikansi 0,031, badan Usaha Milik Desa berpengaruh secara parsial terhadap pendapatan asli desa pada pemerintahan Desa Cilograng tahun anggaran 2018-2020 dengan hasil uji t 7,663 dengan tingkat signifikansi 0,000, alokasi dana desa dan badan usaha milik desa berpengaruh secara simultan terhadap pendapatan asli desa pada pemerintahan Desa Cilograng tahun anggaran 2018-2020 dengan hasil uji f 29,383 dengan tingkat signifikansi 0,000. 


\section{BIBLIOGRAFI}

Arifin, M. Z. (2018). Pengelolaan Anggaran Pembangunan Desa Di Desa Bungin Tinggi, Kecamatan Sirah Pulau Padang, Kabupaten Ogan Komering Ilir, Sumatera Selatan. Jurnal Thengkyang, Http://Jurnaltengkiang. Ac. Id/Jurnal/Index. Php/Jurnaltengkhiang/Issue/View/1/Halaman, 20(20), 1-21.

Astuti, P. B. (2013). Efektivitas Dan Pengaruh Pnpm Mandiri Perdesaan, Alokasi Dana Desa, Pendapatan Asli Desa Dan Jumlah Penduduk Terhadap Jumlah Kepala Keluarga Miskindi Kabupaten Kebumen Tahun 2009-2011. Fokus Bisnis: Media Pengkajian Manajemen Dan Akuntansi, 12(2).

Atmojo, S. T. (2015). Peran Badan Usaha Milik Desa (Bumdes) Dalam Pemberdayaan Masyarakat Desa (Studi Kasus Pada Badan Usaha Milik Desa (Bumdes) Di Desa Temurejo Kecamatan Bangorejo Kabupaten Banyuwangi).

Azwardi, A., \& Sukanto, S. (2014). Efektifitas Alokasi Dana Desa (Add) Dan Kemiskinan Di Provinsi Sumatera Selatan. Jurnal Ekonomi Pembangunan (Journal Of Economics And Development), 12(1), 29-41.

Darmandika, D. (2020). Pengelolan Keuangan Badan Usaha Mlik Desa (Bum Desa) Pernek Berdasarkan Undang-Undang Nomor 6 Tahun 2014 Tentang Desa Dan Permendes Nomor 4 Tahun 2015 Tentang Badan Usaha Milik Desa. Universitas Teknologi Sumbawa.

Hariyanto, S., \& Mutiarin, D. (2016). Dampak Kebijakan Alokasi Dana Desa (Add) Terhadap Pembangunan Desa Di Kabupaten Bulungan Tahun 2011-2014. Journal Of Governance And Public Policy, 2(3).

Jeniary, S. D. (2018). Analisis Rasio Keuangan Pemerintah Desa (Studi Kasus Pada Tujuh Desa Kecamatan Cimenyan Kabupaten Bandung). Universitas Widyatama.

Kadir, A., \& Lubis, Y. (2019). Implementasi Peraturan Menteri Desa Pembangunan Daerah Tertinggal Dan Transmigrasi Nomor 4 Tahun 2015 Tentang Pendirian Pengurusan Dan Pengelolaan Pembubaran Badan Usaha Milik Desa (Bum Desa) Di Desa Sei Limbat Kecamatan Selesai Kabupaten Langkat Sumatera Utara.

Kholmi, M. (2017). Akuntabilitas Pengelolaan Alokasi Dana Desa (Studi Di Desa Kedungbetik Kecamatan Kesamben Kabupaten Jombang). Journal Of Innovation In Business And Economics, 7(2), 143-152.

Kurniawan, H. (2020). Pengaruh Pemahaman Fintech Dan Inklusi Keuangan Terhadap Produktivitas Umkm Di Kota Bandar Lampung. Universitas Muhammadiyah Metro.

Purbasari, H., Wardana, B. W., \& Pangestu, I. A. (2018). Analisis Pengaruh Pendapatan Asli Desa, Dana Desa, Alokasi Dana Desa Dan Bagi Hasil Pajak Dan Retribusi Terhadap Belanja Desa Bidang Pekerjaan Umum Dan Pertanian (Studi Empiris Di 
Seluruh Desa Se-Kabupaten Sukoharjo). Proceeding Of The Urecol, 281-288.

Riza, I. F. (2019). Pengaruh Alokasi Dana Desa (Add) Dan Pendapatan Asli Desa (Padesa) Terhadap Kesejahteraan Masyarakat Desa: Studi Kasus Pada Desa Wringin Anom Kecamatan Asembagus Kabupaten Situbondo. Universitas Islam Negeri Maulana Malik Ibrahim.

Sulistiyoningtyas, L., Zaman, B., \& Tohari, A. (2017). Pengaruh Alokasi Dana Desa Dan Pendapatan Asli Desa Terhadap Belanja Desa Di Kecamatan Baron. Universitas Nusantara. Simki-Economic, 1(03).

Susanto, S., \& Iqbal, M. (2019). Efektifitas Peranan Hukum Dalam Pengelolaan Dana Desa Melalui Bumdes Sebagai Perwujudan Kearifan Lokal Yang Berdaya Saing Guna Meningkatkan Kesejahteraan Rakyat. Proceedings Universitas Pamulang, $1(1)$.

Tomisa, M. E., \& Syafitri, M. (2020). Pengaruh Badan Usaha Milik Desa Terhadap Pendapatan Asli Di Desa Sukajadi Kecamatan Bukit Batu Kabupaten Bengkalis. Iqtishaduna: Jurnal Ilmiah Ekonomi Kita, 9(1), 91-101. 